\title{
Employee Quality Performance, Customer Orientation and Loyalty: Antecedent and Outcome of Customer Satisfaction
}

\author{
Farzana Riva ${ }^{1}$, Nawshin Tabassum Tunna ${ }^{1} \&$ Mohammad Rabiul Basher Rubel $^{2}$ \\ ${ }^{1}$ Department of Business Administration in Marketing, Faculty of Business Studies, Bangladesh University of \\ Professionals, Bangladesh \\ ${ }^{2}$ Department of Business Administration in Management, Faculty of Business Studies, Bangladesh University of \\ Professionals, Bangladesh \\ Correspondence: Mohammad Rabiul Basher Rubel. E-mail: rabiul.basher@bup.edu.bd
}

Received: January 26, 2019

Accepted: March 14, 2019 Online Published: March 29, 2019

doi:10.5539/ass.v15n4p37

URL: https://doi.org/10.5539/ass.v15n4p37

\begin{abstract}
The objective of the current study is to assess the influence of employee quality performance, customer orientation as the antecedents of customer satisfaction and customer loyalty is the outcome of customer satisfaction of restaurant customer in the context of Bangladesh. The anticipated model aims to enhance the understanding of the influence of employee quality performance, customer orientation on customer satisfaction and consequential effect of customer satisfaction on customer loyalty. 295 customers were assessed with a self-administered questionnaire incorporating purposive judgmental sampling that is a non-probability sampling technique. A second-generation data analysis technique-structural equation modeling partial least square (SEM-PLS) was used to analyze the data and to test the hypothesized relationship. The result of the analysis showed a significant positive influence of employee quality performance and customer orientation on customer satisfaction. Moreover, customer satisfaction has been found having a significant positive relationship with customer loyalty. The study can help the management of the restaurants to realize the significance of employee quality performance and customer orientation on customer satisfaction as well as customer satisfaction on loyalty.
\end{abstract}

Keywords: employee quality performance, customer orientation, customer satisfaction, customer loyalty and restaurant in Bangladesh

\section{Introduction}

Due to intense competition among different companies and industries, marketers are bound to apply different strategies and tactics to get their customers as loyal and to maintain the customers' loyalty (Keller, 2008). The paramount importance of customer loyalty has led the academicians and researchers to concentrate on this particular aspect of marketing literature for last three decades (Steinhoff \& Palmatier, 2016). Loyalty is the outcome of successful marketing strategies and tactics. Loyalty of customers can be understood through the exhibited behaviors from the customers such as repeat purchase, allegiance, commitment to the organizations and engagement with the organizations (Azize, Cemal, \& Hakan, 2011). Therefore, customer loyalty can be defined as the behaviors of those customers who purchase repeatedly, recommend the organizations to other customers and hold positive attitudes toward the organizations (Kandampully, Zhang, \& Bilgihan, 2015).

Kandampully et al. (2015) recommended that loyal customer can be a source of organizational growth as well as competitive advantage in the industry. Loyal customers can form the customer base for the marketers. Loyal customers can help the organizations to reduce the costs, increase the efficiency and are more willing to purchase with greater quantity if needed and give more business to their preferred organizations (Castaldo, Grosso, Mallarini, \& Rindone, 2016). So, the results of customer loyalty can be spelled as increased sales volume, more recurrent purchases and customer recommendations to other customers (Yee, Yeung, \& Cheng, 2011). Therefore, it is indispensable for the marketers to identify the relevant strategies and tactics that can help the organizations to make their customers more loyal. If any business organization wants to make their customers loyal, its prime concern should be to focus on making the customer more satisfied than their rivals in the target market (Chocholáková, Gabčová, Belás, \& Sipko, 2015; Gopalkrishnan, Mishra, Gupta, \& Vetrivel, 2011). Thus, customer satisfaction is the prerequisite to have loyal customers. 
Customer satisfaction is widely used tool to make the customers loyal and used as a key concept in the business particularly in services industry. If the organizations are not able to satisfy their customers, the consequential effect is less attachment with the organization from the customers. When the customers are not satisfied it can increase the switching tendencies of the customers and ultimate switch to competitive organization (Hill \& Alexander, 2017). Researchers also recommended focusing on customer satisfaction that can help the organization to make their customers more loyal (Steinhoff \& Palmatier, 2016). In a recent study, Hussain, Al-Nasser \& Hussain (2015) also found different dimensions as predictors of customer satisfaction such as service quality (Li, Ye, \& Law, 2013), customer relationship management (Khodakarami \& Chan, 2014), customer value proposition (Flint \& Woodruff, 2014).

Many other studies also found different predictors of customer satisfaction such as employee quality performance, customer orientation, corporate social responsibility, dining environment and food quality of restaurants (Izogo, \& Ogba, 2015; Lee, Lee, \& Kang, 2012; Korschun, Bhattacharya, \& Swain, 2014). Whereas, many other researchers focused on different outcomes of customer satisfaction such as customer loyalty, purchase with larger quantity, revisit intention (Hill \& Alexander, 2017), purchase behavior (Orel \& Kara, 2014), repurchase intention and repurchase behavior (Pappas, Pateli, Giannakos, \& Chrissikopoulos, 2014). Based on the previous literature it can be proclaimed that there are few studies that tried to find customer satisfaction is the focus of employee quality performance and customer orientation as well as customer loyalty is the outcome variable of customer satisfaction in the context of hospitality and tourism industry. Furthermore, in earlier research researchers have tried to identify the effect of customer satisfaction on customer loyalty on different time frame in different industries whereas hospitality and tourism industry is still unexplored in the context of developing countries (Khan, \& Fasih, 2014). Owing to this research gap in the context of developing countries like Bangladesh, the current study focus on employee quality performance and customer orientation as antecedents of customers' satisfaction and customer loyalty is the outcome of customer satisfaction. More specifically, in the context of restaurant business in Bangladesh there is a paucity of research in this regard. Thus, from the previous literature support it can be said that the current study will provide an avenue to the practitioners to link the research outcome of the current study for the development of the restaurant customers' satisfaction and loyalty. Therefore, the current study tried to obtain the following objectives and developed the following theoretical framework.

1. To find the effect of employee quality performance on restaurant customers' satisfaction.

2. To find the effect of customer orientation on restaurant customers' satisfaction

3. To identify the effect of restaurant customers' satisfaction on customer loyalty.

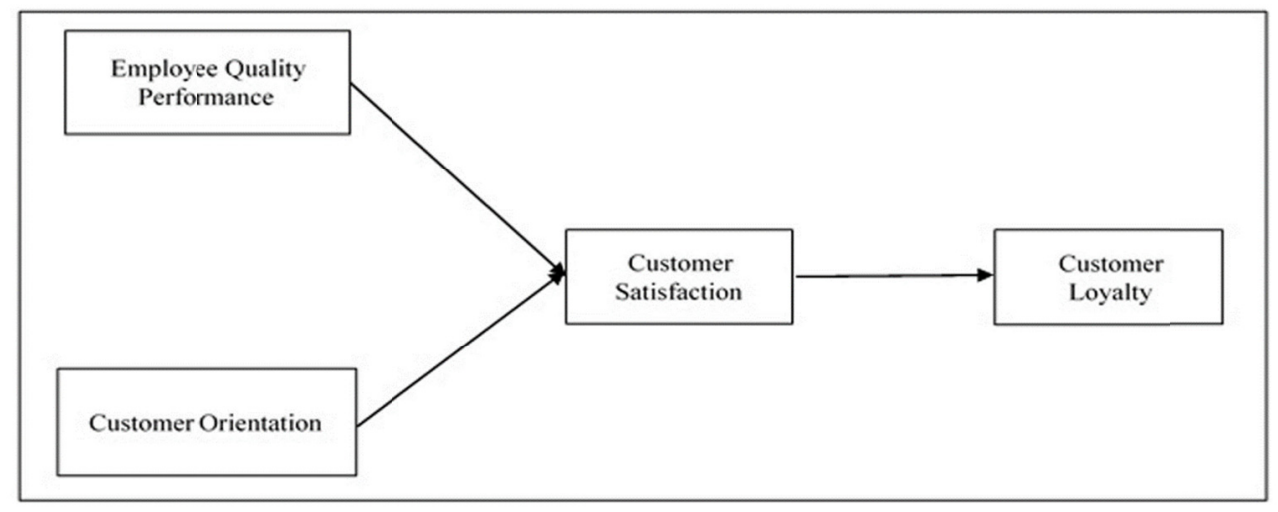

Figure 1. Proposed Study Framework

\section{Literature Review and Hypothesis}

\subsection{Service Quality Performance and Customer Satisfaction}

In this heightened competition era the employee service quality performance is now considered an essential strategy. Success of any service provider in the long run is closely associated with high-quality customer services that determines the extent of customer satisfaction and loyalty (Lymperopoulos, Chaniotakis, \& Soureli, 2006; Hussain et al., 2015). From previous literature employee quality performance can be found in different firms such as friendly employees, responsive employees, empathetic employees, employee's knowledge, helpful employees, accuracy of billing, accuracy of services, billing timeliness, and quick services (Zeng, Phan, \& 
Matsui, 2015; Zehir, Ertosun, Zehir, \& Müceldilli, 2012).

Employee quality performance can be spelled as employee satisfaction that helps them to perform better and serve for minimizing customer absenteeism, tardiness and enhance commitment to the organization (Zehir et al., 2012). Quality services can ensure the customer satisfaction that is the most challenging goal to obtain but important aspects that is faced by the recent service industries (Carter, Armenakis, Field, \& Mossholder, 2013). Employee quality performance of service quality is closely related to customer satisfaction that also helps to evaluate the performance of service organizations in the light of service providers (Zhao, Lu, Zhang, \& Chau, 2012). A new concept had been introduced by Ladhari (2009) named as HOLSERV that is used specifically in lodging and hospitality industry. According to HOLSERV concept employee reliability, employee performance quality and other tangibles aspects of intangible services can help to evaluate the service quality for lodging and hospitality industry. As a result, managers of this particular industry are giving more concern on retaining the employees who can provide superior value to their customers by quality performance (Amin, Yahya, Ismayatim, Nasharuddin, \& Kassim, 2013; Berezina, Bilgihan, Cobanoglu, \& Okumus, 2016).

Traditional marketing literature and identification theory recommended that front-line employees in the service organization have direct interaction with the customer where the customer satisfaction largely depends on the performance of the employees. Employees' quality performance can also determine organizational performance in terms of having satisfied and loyal customers (Adzoyi, Jan Blomme, \& Honyenuga, 2018). In previous literature (Sekulic \& Mandaric, 2014) also found the same conception that employee performance can ensure the quality services of the organization that can be considered an indispensable element of customer satisfaction. From the conceptualization of the service profit chain (S-PC), it can be said that overall service value perceived by customer is closely linked with customer satisfaction and it depends largely on the performance of the employees (Marković \& Raspor Janković, 2013; Benavides-Velasco, Quintana-García, \& Marchante-Lara, 2014). The justification behind this belief is that better services approached by the organization can lead to increased satisfaction among customers (Ryu, Lee, \& Gon Kim, 2012; Subramanian, Gunasekaran, Cheng, \& Ning, 2014). In the context of Bangladesh, Mazumder \& Hasan, (2014) initiated to clarify the association between customer expected services and their satisfaction in hotel business. These authors have found that the employee quality performance has positive effect on the performance of the organization. This rationale is perceived as a most important and common practice in the service industry especially for lodging and hotel services. Therefore, from the previous literature support it can be considered that employee quality performance in the restaurant business can determine the success of restaurants business by exerting influences on customer satisfaction. Thus, grounded on the literature support the current study deliberates the following hypothesis;

Hypothesis 1: Employee quality performance is positively associated with customer satisfaction.

\subsection{Customer Orientation and Customer Satisfaction}

Extant literature on social identification theory is increasing for customer attitudinal outcome such as customer satisfaction and customer loyalty ( $\mathrm{He}, \mathrm{Li}, \&$ Keung Lai, 2011). Customers are the king and being the non-formal members of a company can develop robust and long-lasting identification and close association with business organizations $(\mathrm{He} \& \mathrm{Li}, 2011)$. Based on the literature support customer orientation can be defined as the understanding of the target markets that enable them to create superior value for the customers according to customers' expectation (Narver, Slater, \& MacLachlan, 2004; Homburg, Müller, \& Klarmann, 2011). It is also suggested by the researchers that organizational performance can be attained through providing greater value to customers that largely depend on having appropriate customer orientation throughout the organization (Grissemann, Plank, \& Brunner-Sperdin, 2013).

According to the previous literature the impact of customer orientation can be discussed in terms of two aspects that are closely related with customer satisfaction such as value-based customer orientation (Wang, Chen \& Chen, 2012) and action-based customer orientation (He et al., 2011). Value-based customer orientation focuses to fulfill customer needs by being knowledgeable about customers' expectation for service quality and it can determine customer satisfaction (Blocker, Flint, Myers, \& Slater, 2011). Whereas other aspect focuses on the usage of feedback from customers and accommodation of those feedback while taking organizational decision that is known as action-based customer orientation (He et al., 2011). According to this definition it can be said that the service organizations with customer orientation take every decision according to expectation of service quality of their customers and incorporate the slogans such as "Customers are always right", and "Customers are our God", and it can be resulted in the customer satisfaction. Customers can easily rely on the business organization and they form a belief that they are important for the organizations and are more prone to be satisfied with services from that organization (Kibbeling, Van Der Bij, \& Van Weele, 2013). 
Therefore, employees in the organization can better comprehend that the customers are important and can concentrate more on customer satisfaction by providing superior value than their rivals (Wu, Tsai, \& Fu, 2013). When employees are informed that the customers are important for the performance of the organizations, they put more emphasis on providing superior customer service. Moreover, employees are more likely to respond by investing more time and energy in providing quality service to the customers. Consequently, the customers become more satisfied with the services (Gazzoli, Hancer, \& Kim, 2013). So, customer orientation can increase the performance of the organization in terms of providing superior value to the target customer (Grissemann et al., 2013), enhance bonding with the customer (Wang \& Feng, 2012), result in higher revenue for the organization as well as result in customer satisfaction (Rodriguez, Peterson, \& Ajjan, 2015). With this notion the following hypothesis for this study can be proposed;

Hypothesis 2: Customer orientation is positively related with customer satisfaction.

\subsection{Customer Satisfaction and Customer Loyalty}

There is a notion that, customer satisfaction has the influence on organizational growth and profitability. Therefore, making the customer more satisfied is the vital of any organization (Saeidi, Sofian, Saeidi, Saeidi, \& Saaeidi, 2015). Customer satisfaction is being a dominant concept in marketing literature can be considered as important goal of all business activities (Deesomlert \& Sawmong, 2013; Bhat \& Darzi, 2016). Therefore, customer satisfaction is considered as the vital for customer loyalty (Yuksel, Yuksel, \& Bilim, 2010). It has been found in the literature of lodging industry that the participants of this industry are thriving for customer satisfaction and are giving extra priorities to ensure that their customers are satisfied with the services offered (Ali \& Amin, 2014). The outcome of customer satisfaction in hotel industry is considered with paramount importance that can give future business for the hotel and restaurant organization and can improve organizational economic performance in terms of increased sales (Kandampully et al., 2015).

Satisfied customers of any organization can enhance the growth of the organization by giving extra businesses in terms of increased sales (Rose, Clark, Samouel, \& Hair, 2012). Rose et al. (2012) and (Han \& Hyun, 2015) found the significant positive impact of customer satisfaction on customer loyalty. These authors revealed that when customers get their expected services, they become satisfied with the services of the organizations and the consequential outcome is the loyalty to that organization from the customers. They also mentioned that the satisfied customers are more interested to develop long-term attachment with the business organization.

Therefore, customers' loyalty can be developed over a period of time from series of transaction with the service providers who can satisfy the customers. The authors also claimed that if the organizations are able to provide the expected services to their customer the result can be customer loyalty (Lee, Capella, Taylor, \& Gabler, 2014). Restaurant service providers' ability to retain customers will depend on how they can satisfy their customers and encourage them to make repeat purchases (Yee et al., 2011; Keisidou, Sarigiannidis, Maditinos, \& Thalassinos, 2013). Thus, based on the previous literature support it can be claimed that if the organization can make their customer more satisfied the outcome will be loyalty from the customers for that organization. Therefore, in this regard the following hypothesis can be considered;

Hypothesis 3: Customer satisfaction is positively related with customer loyalty in restaurant business.

\section{Methodology}

\subsection{Population and Sample}

The nature of the current study was cross-sectional where data were gathered, and conclusion was drawn at a specific point of time. The study focused on the restaurant customer in the Dhaka city, the capital of Bangladesh. According to the Bangladesh Restaurant Society and Association (2017) majority of the restaurants are located in Dhaka. Moreover, within last 2 years 453 new restaurants have been established due to the increased demand in Dhaka City (Bangladesh Bureau of Statistics, 2017) Therefore, Dhaka was considered as the sampling frame of the current study. For collecting data of the current study, the researchers communicated to the different restaurants in different areas of Dhaka city. Purposive judgmental sampling technique has been used in the current study. Judgmental sampling technique is a segment of purposive sampling method of nonprobability sampling design. This specific technique is restricted to special categories of participants who can be a source of the expected information, as they are the group who holds it, or coincide to some assumptions fixed by the researchers (Sekaran \& Bougie, 2010). According to Hair, Hult, Ringle, Sarstedt \& Thiele, (2017) Judgmental sampling technique is suitable when there is no complete list of the respondents. Previous researches in the context of Bangladesh also employed judgmental sampling method for study (Rubel \& Kee, 2015; Rubel, Rimi, Yusliza, \& Kee, 2018). 
In this study, a total of 800 questionnaires were distributed to the different restaurants where 315 were returned with a response rate of $39.37 \%$. Among these 315 questionnaires 20 were not used to analyze the data due to incompleteness and insufficient information. Therefore, 295 questionnaires were found usable and suitable to analyze the data with a response rate of $36.87 \%$. Rubel, Rimi, Kee and Yusliza (2017) had found only 30\% responses in their study in banking industry in Bangladesh and found the outcome as satisfactory. Furthermore, in Partial Least Square (PLS) analysis 100 samples are sufficient to analyze the data (Hair et al., 2017). Thus, the response rate of the current study is considered acceptable for data analysis.

The current study used both SPSS statistical analytical package (version 21) and Smart PLS M 2.0 for data analysis and hypothesis testing. SPSS was used for data entry and examination of other descriptive analysis whereas, PLS was considered for assessing both outer and inner model as well as the coefficient of the model. The average value of the latent constructs of the current study ranges from 3.81 to 4.06 . Here the highest mean value showed for customer loyalty and lowest value represented for employee quality performance. The highest and lowest standard deviation (S.D) value also found for the same variables. Moreover, the demographic information represents that more than one-third of the respondents' age ranges from 36 to 45 (43\%). Out of 295 respondents, $76 \%$ were identified as unmarried and more than two-third of the respondents $(72 \%)$ having higher secondary school certificates.

\subsection{Measurement Instrument}

Outcome variable of the current research is the Loyalty that has been measured by three items adapted from the previous work of Aydin \& Ozer (2005). Again, the customer satisfaction is considered as focus variable measured by three items and had been adapted of the study of (Homburg et al., 2011). Reliability value of these two variables was reported as 0.77 and 0.81 respectively and considered acceptable. Furthermore, two antecedent constructs employee quality performance and customer orientation were adapted from the previous validated scale of Cronin Jr, Brady \& Hult, (2000) with 9 and 5 items respectively. Alpha value of both the constructs found acceptable with the value of 0.78 and 0.83 respectively.

\section{Results of the Analysis}

\subsection{Measurement Model}

For assessing the goodness of measurement model, the researchers need to examine both convergent and discriminant validity. To determine this magnitude to which the construct is with similar meaning or same, convergent validity has been used by assessing the loading of the individual items, AVE and CR (Hair et al., 2017). In this regard the minimum acceptable value for loading, AVE and CR were considered 0.5 both for loading and AVE, and 0.7, for CR respectively (Hair et al., 2017). Based on the criterion three items were deleted from employee quality performance (EQP5, EQP6, and EQP 8) due to the loading found lower than the recommended value. Table 1 displays the loadings, AVE and CR of all the constructs.

Table 1. Result of Measurement Model

\begin{tabular}{lcccc}
\hline Constructs & Measurement Items & Loading & AVE & CR \\
\hline Customer Orientation & CO 1 & 0.738 & 0.569 & 0.868 \\
& CO 2 & 0.820 & & \\
CO 3 & 0.797 & & \\
CO 4 & 0.747 & & \\
CO 5 & 0.661 & & 0.846 \\
Employee Quality & EQP 1 & 0.702 & 0.518 & \\
Performance & EQP 2 & 0.616 & & \\
& EQP 3 & 0.692 & & \\
EQP 4 & 0.679 & & \\
Loyalty & EQP 7 & 0.768 & & \\
EQP 9 & 0.682 & & \\
& LOY & 0.892 & 0.783 & \\
& LOY TAL 1 & & \\
& LOY 2 & 0.861 & & \\
& SATIS 1 & 0.901 & & \\
& SATIS 2 & 0.921 & 0.790 & \\
\hline
\end{tabular}


Next, discriminant validity has been measured to find out to what extent items are competent to separate between variables or to assess distinct thoughts (Fornell \& Larcker, 1981; Rubel, Kee, \& Rimi, 2017). For this study, the discriminant validity was found to be acceptable where all the diagonal value found higher than all the off-diagonal.

Table 2. Discriminant Validity Table

\begin{tabular}{ccccc}
\hline & CO & EQP & LOYALTY & SATIS \\
\hline CO & $\mathbf{0 . 7 5 4}$ & & & \\
EQP & 0.294 & $\mathbf{0 . 7 2 0}$ & & \\
LOYALTY & 0.300 & 0.171 & $\mathbf{0 . 8 8 5}$ & \\
SATIS & 0.314 & 0.201 & 0.338 & $\mathbf{0 . 8 3 9}$ \\
\hline Mean & 3.87 & 3.81 & 4.06 & 3.95 \\
S.D & 0.71 & 0.69 & 0.81 & 0.74 \\
\hline
\end{tabular}

\subsection{Structural Model}

Structural model reveals the linkage of the variables formed for the research model (Santhanamery \& Ramayah, 2015; Rubel et al., 2018). The relative importance of the path estimates for a study and the variance that can be explained $\left(\mathrm{R}^{2}\right)$ by the endogenous variables can be understood by the goodness of the proposed theoretical model (Chin, 2010). The proposed model is being investigated by the data through the calculation of the $\mathrm{R}^{2}$ and the path coefficients (Chin, 2010). Moreover, bootstrapping analysis had been used that is a technique of re-sampling. Bootstrapping analysis generates a bootstrap sample in order to get the standard error of the hypothesis testing and it is done by using repeated random sampling instead of using the original sample (Cordeiro et al., 2010). The significance of each path coefficient can be measured with the help of bootstrapping techniques that displays the significance of the hypothesized direction to support the developed causal association and vice-versa (Hair et al., 2017).

$31 \%$ variance of customer satisfaction (focus variable) can be explained by employee quality performance and customer orientation that considered the antecedent of customer satisfaction in the current study. On the other hand, customer loyalty is the outcome of the current study that can be explained (38\%) by customer satisfaction. Table 3 showed the outcome of the structural model. The findings of the analysis showed both the antecedents such as employee quality performance $(\beta=0.0 .119, \mathrm{p}<0.01)$ and customer orientation $(\beta=0.279, \mathrm{p}<0.01)$ are positively related with customer satisfaction. On other hand, customer satisfaction also showed a positive significant association with customer loyalty $(\beta=0.0 .338, \mathrm{p}<0.01)$. Hence, the result shows that H1, H2 and $\mathrm{H} 3$ are accepted for the current study.

Table 3. Results of the Hypothesis Test

\begin{tabular}{lcccc}
\hline \multicolumn{1}{c}{ Path Relationship } & Std. Beta & Std. Error & t Value & Decision \\
\hline Employee Quality Performance $>$ Satisfaction & 0.119 & 0.050 & $2.397 * *$ & Accepted \\
Customer Orientation > Satisfaction & 0.279 & 0.050 & $5.567 * *$ & Accepted \\
Satisfaction $>$ Customer Loyalty & 0.338 & 0.043 & $7.905 * *$ & Accepted \\
\hline Note: $* * p<0.01,(1000$ bootstrapping with One-tailed test) & & & \\
\hline
\end{tabular}

\section{Discussion}

The current study tried to fill the gap that is unexplored yet by the previous studies. Past researchers have evidently identified different antecedents and consequences of customers' loyalty in the context of developed countries and in other industries (Gopalkrishnan et al., 2011; Bhat \& Darzi, 2016; Lee et al., 2012). The current study reveals the findings that employee quality performance and customer orientation have positive influence on customer satisfaction for the restaurant business. The result of this study clearly signifies that employee quality performance and customer orientation can be regarded as the significant predictors having influence on customer satisfaction. Earlier studies have also proved the importance of employee quality performance for satisfying the customers (Mazumder \& Hasan, 2014; Kandampully et al., 2015; Jauhari \& Bharwani, 2017). The authors have suggested that the customer satisfaction in the lodging and hospitality industry can be attained with the help of two elements: one is functional (i.e., the food and beverage in a restaurant) and the other is 
performance-delivery that means the employee quality performance while providing the services. The current study findings correspond to the previous study findings.

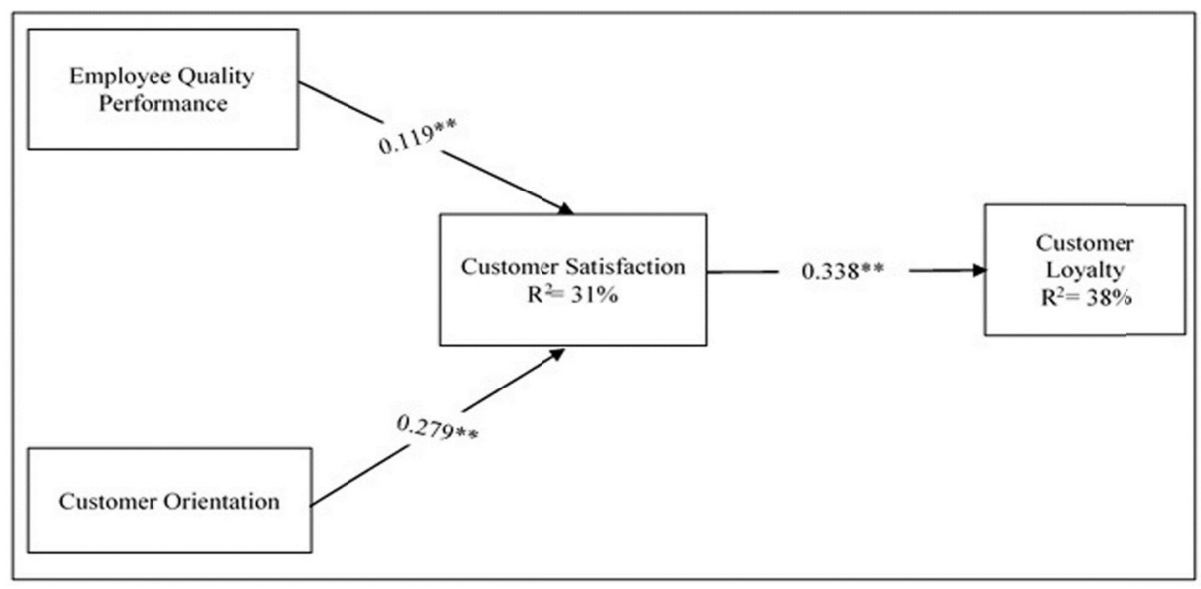

Figure 2. Structural Model

In the context of Bangladesh, Uddin \& Akhter (2012) suggested that the quality performance of the employees in the services organizations play significant role to satisfy customers. Therefore, based on the previous literature support along with the findings of the current study it can be said that if the employees perform properly and provide superior services to the customers in the restaurant organization the customers will be more satisfied. Again, it can be assumed that organizations will provide more support to their employees that will motivate the employees to provide superior value to their customers through quality performance. Lastly, it can be said that if employees find appropriate and conducive environment to perform in a better way which can help them to find more satisfied customer. Melián-González \& Bulchand-Gidumal, (2016) also found that the performance of the hotels largely depends on the quality performance of the employees.

Another objective of the current study was to assess the impact of customer orientation on customer satisfaction. The result of the analysis showed a significant positive relationship between customer orientation and customer satisfaction. The finding of the current study is consistent with the previous studies (Ramani \& Kumar, 2008; Ha \& Jang, 2010; Blut, Frennea, Mittal, \& Mothersbaugh, 2015; Jauhari \& Bharwani, 2017). These authors clarified that proper orientation of customer helps the organizations to make their customers more satisfied with the services. In other words, it can be proclaimed that if the restaurants become more concern to know about their customer expectation and accommodate them while taking decision and designing strategies and tactics the consequential outcome is the customer satisfaction.

Therefore, based on the literature support and the result of the current study the following notion can be considered such as, if the restaurant businesses become customer oriented, the businesses will have more satisfied customers with the provided services. Furthermore, it can be assumed that if the business organizations give appropriate concern to their customer need and demands, the outcome will be to have more satisfied customers. Lastly, it can also be considered that when customers are well privileged based on their opinion in the organization it can lead to their satisfaction while receiving the services. Thus, based on the findings of the analysis and the past literature evidence and justification, the positive effect of customer orientation on customer satisfaction proved the hypothesized connection.

Finally, this study focused on customer loyalty as outcome of customer satisfaction which also found significant positive relationship. This relationship also found significant in the previous literature (Ramaseshan, Rabbanee, \& Tan Hsin Hui, 2013; Hussain et al., 2015; Izogo \& Ogba, 2015; Berezina et al., 2016; Su, Swanson, \& Chen, 2016). These authors revealed that satisfied customer can be considered as the valuable resources for the organizations and need to retain through appropriate strategies to increase the performance of the organization. Thus, it can be clarified that if the restaurants can make their customers more satisfied with their services the consequential outcome will be more loyal customers. In the context of restaurant business in Bangladesh it has also been found significant due to several reasons. First, it can be assumed that customer in the restaurant in Bangladesh have the chance to explore their views and ideas regarding their anticipations which also helps the organization to remain them in long run. Second, it can be considered that customers have the power and scope to determine and implement their decision in the restaurants. Therefore, from the findings and the literature 
justification the result of the current study considered acceptable.

\section{Conclusion and Limitations}

Therefore, from the ultimate perspective of customer loyalty it is essential to focus on customer satisfaction and customer loyalty is behavioral outcome of customer satisfaction. Services organizations should gather knowledge about how they can enhance the level of customer satisfaction that helps them to have loyal customers. The present study reveals that employee quality performance and customer orientation are the ways to achieve this purpose. Management of any business organization should focus on improving employee performance in terms of providing quality services to their customers. Thus, decision makers of any service organization should believe if they want to have satisfied and loyal customers, they should work on employee quality performance and emphasize on customer. Moreover, it is an utmost importance for organization to focus on customer satisfaction which can improve the financial performance of the organization.

Like other research this study has several limitations. This study has considered only the customers of some selected restaurants of Dhaka Therefore, the findings of the current study cannot generalized for the whole industry and the other industry in Bangladesh. Second, this study only considers two predictors of customer satisfaction whereas, many other factors may have significant influence on satisfaction of restaurants customers. Therefore, it is suggesting to the future researchers and practitioners to consider other predictors and outcome of customer satisfaction in hotel and lodging industry. So, more studies are felt important in this regard.

\section{References}

Adzoyi, P. N., Jan Blomme, R., \& Honyenuga, B. Q. (2018). Customer Retention among Hotels in an Emerging Market: An Employee-Based Perspective. In Advances in Hospitality and Leisure (pp. 57-73). Emerald Publishing Limited.

Ali, F., \& Amin, M. (2014). The influence of physical environment on emotions, customer satisfaction and behavioural intentions in Chinese resort hotel industry. Journal for Global Business Advancement, 7(3), 249-266. https://doi.org/10.1504/jgba.2014.064109

Amin, M., Yahya, Z., Ismayatim, W. F. A., Nasharuddin, S. Z., \& Kassim, E. (2013). Service quality dimension and customer satisfaction: An empirical study in the Malaysian hotel industry. Services Marketing Quarterly, 34(2), 115-125. https://doi.org/10.1080/15332969.2013.770665

Aydin, S., \& Özer, G. (2005). The analysis of antecedents of customer loyalty in the Turkish mobile telecommunication market. European Journal of Marketing, 39(7/8), 910-925. https://doi.org/10.1108/03090560510601833

Benavides-Velasco, C. A., Quintana-García, C., \& Marchante-Lara, M. (2014). Total quality management, corporate social responsibility and performance in the hotel industry. International Journal of Hospitality Management, 41, 77-87. https://doi.org/10.1016/j.ijhm.2014.05.

Berezina, K., Bilgihan, A., Cobanoglu, C., \& Okumus, F. (2016). Understanding satisfied and dissatisfied hotel customers: Text mining of online hotel reviews. Journal of Hospitality Marketing \& Management, 25(1), 1-24. https://doi.org/10.1080/19368623.2015.983631

Bhat, S. A., \& Darzi, M. A. (2016). Customer relationship management: An approach to competitive advantage in the banking sector by exploring the mediational role of loyalty. International Journal of Bank Marketing, 34(3), 388-410.

Blocker, C. P., Flint, D. J., Myers, M. B., \& Slater, S. F. (2011). Proactive customer orientation and its role for creating customer value in global markets. Journal of the Academy of Marketing Science, 39(2), 216-233. https://doi.org/10.1007/s11747-010-0202-9

Blut, M., Frennea, C. M., Mittal, V., \& Mothersbaugh, D. L. (2015). How procedural, financial and relational switching costs affect customer satisfaction, repurchase intentions, and repurchase behavior: A meta-analysis. International Journal of Research in Marketing, 32(2), 226-229. https://doi.org/10.1016/j.jiresmar.2015.01.001

Carter, M. Z., Armenakis, A. A., Feild, H. S., \& Mossholder, K. W. (2013). Transformational leadership, relationship quality, and employee performance during continuous incremental organizational change. Journal of Organizational Behavior, 34(7), 942-958. https://doi.org/10.1002/job.1824

Castaldo, S., Grosso, M., Mallarini, E., \& Rindone, M. (2016). The missing path to gain customers loyalty in pharmacy retail: The role of the store in developing satisfaction and trust. Research in Social and 
Administrative Pharmacy, 12(5), 699-712. https://doi.org/10.1016/j.sapharm.2015.10.001

Chin, W. W. (2010). How to write up and report PLS analyses. In Handbook of partial least squares (pp. 655-690). Springer, Berlin, Heidelberg.

Cordeiro, D., Mounié, G., Perarnau, S., Trystram, D., Vincent, J. M., \& Wagner, F. (2010). Random graph generation for scheduling simulations. In Proceedings of the $3 r d$ international ICST conference on simulation tools and techniques (p. 60). ICST (Institute for Computer Sciences, Social-Informatics and Telecommunications Engineering).

Chochol'áková, A., Gabčová, L., Belás, J., \& Sipko, J. (2015). Bank customers'satisfaction, customers' loyalty and additional purchases of banking products and services. A case study from the Czech Republic. Economics and Sociology. https://doi.org/10.14254/2071-789X.2015/8-3/6

Cronin Jr, J. J., Brady, M. K., \& Hult, G. T. M. (2000). Assessing the effects of quality, value, and customer satisfaction on consumer behavioral intentions in service environments. Journal of retailing, 76(2), 193-218. https://doi.org/10.1016/s0022-4359(00)00028-2

Deesomlert, S., \& Sawmong, S. (2013). Factors influencing service innovation and business performance of spa for health in Thailand: Emprical study. International Journal of Business, Marketing, \& Decision Science, 6(1), 136-156.

Fornell, C., \& Larcker, D. F. (1981). Evaluating structural equation models with unobservable variables and measurement error. Journal of Marketing Research, 18(1), 39-50. https://doi.org/10.2307/3151312

Flint, D. J., \& Woodruff, R. B. (2014). Marketing's service-dominant logic and customer value. In The Service-Dominant Logic of Marketing (pp. 201-213). Routledge.

Gazzoli, G., Hancer, M., \& Kim, B. (2013). Explaining why employee-customer orientation influences customers' perceptions of the service encounter. Journal of Service Management, 24(4), 382-400. https://doi.org/10.1108/JOSM-09-2012-0192

Gopalkrishnan, J., Mishra, B. B., Gupta, V. K., \& Vetrivel, A. (2011). The impact of service quality and customer satisfaction on customer retention in the Indian banking industry: An empirical analysis. Research Journal of Social Science and Management, 1(3), 52-68.

Grissemann, U., Plank, A., \& Brunner-Sperdin, A. (2013). Enhancing business performance of hotels: The role of innovation and customer orientation. International Journal of Hospitality Management, 33, 347-356. https://doi.org/10.1016/j.ijhm.2012.10.005

Ha, J., \& Jang, S. (2010). Perceived Values, Satisfaction, and Behavioral Intentions: The Role of Familiarity in Korean Restaurants. International Journal of Hospitality Management, 29, 2-13. https://doi.org/10.1016/j.ijhm.2009.03.009

Hair, J. F., Hult, G. T. M., Ringle, C. M., Sarstedt, M., \& Thiele, K. O. (2017). Mirror, mirror on the wall: A comparative evaluation of composite-based structural equation modeling methods. Journal of the Academy of Marketing Science, 45(5), 616-632. https://doi.org/10.1007/s11747-017-0517-x

Han, H., \& Hyun, S. S. (2015). Customer retention in the medical tourism industry: Impact of quality, satisfaction, trust, and price reasonableness. Tourism Management, 46, 20-29. https://doi.org/10.1016/j.tourman.2014.06.003

He, H., \& Li, Y. (2011). CSR and service brand: The mediating effect of brand identification and moderating effect of service quality. J. of Business Ethics, 100, 673-688. https://doi.org/10.1007/s10551-010-0703-y

He, Y., Li, W., \& Keung Lai, K. (2011). Service climate, employee commitment and customer satisfaction: Evidence from the hospitality industry in China. International Journal of Contemporary Hospitality Management, 23(5), 592-607. https://doi.org/10.1108/09596111111143359

Hill, N., \& Alexander, J. (2017). The handbook of customer satisfaction and loyalty measurement. Routledge.

Homburg, C., Müller, M., \& Klarmann, M. (2011). When does salespeople's customer orientation lead to customer loyalty? The differential effects of relational and functional customer orientation. Journal of the Academy of Marketing Science, 39(6), 795-812. https://doi.org/10.1007/s11747-010-0220-7

Hussain, R., Al Nasser, A., \& Hussain, Y. K. (2015). Service quality and customer satisfaction of a UAE-based airline: An empirical investigation. Journal of Air Transport Management, 42, 167-175. https://doi.org/10.1016/j.jairtraman.2014.10.001 
Izogo, E. E., \& Ogba, I. E. (2015). Service quality, customer satisfaction and loyalty in automobile repair services sector. International Journal of Quality \& Reliability Management, 32(3), 250-269. https://doi.org/10.1108/ijqrm-05-2013-0075

Jauhari, V., \& Bharwani, S. (2017). An exploratory study of competencies required to cocreate memorable customer experiences in the hospitality industry. In Hospitality Marketing and Consumer Behavior (pp. 159-185). Apple Academic Press.

Kandampully, J., Zhang, T., \& Bilgihan, A. (2015). Customer loyalty: A review and future directions with a special focus on the hospitality industry. International Journal of Contemporary Hospitality Management, 27(3), 379-414. https://doi.org/10.1108/ijchm-03-2014-0151

Keisidou, E., Sarigiannidis, L., Maditinos, D. I., \& Thalassinos, E. I. (2013). Customer satisfaction, loyalty and financial performance: A holistic approach of the Greek banking sector. International Journal of Bank Marketing, 31(4), 259-288. https://doi.org/10.1108/IJBM-11-2012-0114

Keller, K. L. (2008). Strategic Brand Management: Building, Measuring and Managing Brand Equity (3rd ed.). New Jersey: Pearson Prentice Hall.

Khan, M. M., \& Fasih, M. (2014). Impact of service quality on customer satisfaction and customer loyalty: Evidence from banking sector. Pakistan Journal of Commerce and Social Sciences, 8(2), 331.

Khodakarami, F., \& Chan, Y. E. (2014). Exploring the role of customer relationship management (CRM) systems in customer knowledge creation. Information \& Management, 51(1), 27-42. https://doi.org/10.1016/j.im.2013.09.001

Kibbeling, M., Van Der Bij, H., \& Van Weele, A. (2013). Market orientation and innovativeness in supply chains: Supplier's impact on customer satisfaction. Journal of Product Innovation Management, 30(3), 500-515. https://doi.org/10.1111/jpim.12007

Korschun, D., Bhattacharya, C. B., \& Swain, S. D. (2014). Corporate social responsibility, customer orientation, and the job performance of frontline employees. Journal of Marketing, 78(3), 20-37. https://doi.org/10.1509/jm.11.0245

Ladhari, R. (2009). Service quality, emotional satisfaction, and behavioural intentions: A study in the hotel industry. Managing Service Quality: An International Journal, 19(3), 308-331.

Lee, J. J., Capella, M. L., Taylor, C. R., \& Gabler, C. B. (2014). The financial impact of loyalty programs in the hotel industry: A social exchange theory perspective. Journal of Business Research, 67(10), 2139-2146. https://doi.org/10.1016/j.jbusres.2014.04.023

Lee, S. M., Lee, D., \& Kang, C. Y. (2012). The impact of high-performance work systems in the health-care industry: Employee reactions, service quality, customer satisfaction, and customer loyalty. The Service Industries Journal, 32(1), 17-36. https://doi.org/10.1080/02642069.2010.545397

Li, H., Ye, Q., \& Law, R. (2013). Determinants of customer satisfaction in the hotel industry: An application of online review analysis. Asia Pacific Journal of Tourism Research, 18(7), 784-802. https://doi.org/10.1080/10941665.2012.708351

Lymperopoulos, C., Chaniotakis, I. E., \& Soureli, M. (2006). The importance of service quality in bank selection for mortgage loans. Managing Service Quality, 16(4), 365-379. https://doi.org/10.1108/09604520610675702

Marković, S., \& Raspor Janković, S. (2013). Exploring the relationship between service quality and customer satisfaction in Croatian hotel industry. Tourism and Hospitality Management, 19(2), 149-164.

Mazumder, S., \& Hasan, A. B. M. R. (2014). Measuring service quality and customer satisfaction of the hotels in Bangladesh: A study on national and international hotel guest. Journal of Tourism and Hospitality Management, 2(1), 95-111.

Melián-González, S., \& Bulchand-Gidumal, J. (2016). A model that connects information technology and hotel performance. Tourism Management, 53, 30-37. https://doi.org/10.1016/j.tourman.2015.09.005

Narver, J. C., Slater, S. F., \& MacLachlan, D. L. (2004). Responsive and proactive market orientation and newproduct success. Journal of product innovation management, 21(5), 334-347.

Pappas, I., G. Pateli, A., N. Giannakos, M., \& Chrissikopoulos, V. (2014). Moderating effects of online shopping experience on customer satisfaction and repurchase intentions. International Journal of Retail \& 
Distribution Management, 42(3), 187-204. https://doi.org/10.1108/ijrdm-03-2012-0034

Orel, F. D., \& Kara, A. (2014). Supermarket self-checkout service quality, customer satisfaction, and loyalty: Empirical evidence from an emerging market. Journal of Retailing and Consumer Services, 21(2), 118-129. https://doi.org/10.1016/j.jretconser.2013.07.002

Ramani, G., \& Kumar, V. (2008). Interaction Orientation and Firm Performance. Journal of Marketing, 72(1), 27-45. https://doi.org/10.1509/jmkg.72.1.27

Ramaseshan, B., Rabbanee, F. K., \& Tan Hsin Hui, L. (2013). Effects of customer equity drivers on customer loyalty in B2B context. Journal of Business \& Industrial Marketing, 28(4), 335-346. https://doi.org/10.1108/08858621311313929

Rodriguez, M., Peterson, R. M., \& Ajjan, H. (2015). CRM/social media technology: Impact on customer orientation process and organizational sales performance. In Ideas in Marketing: Finding the New and Polishing the Old (pp. 636-638). Springer, Cham. https://doi.org/10.1007/978-3-319-10951-0_233

Rose, S., Clark, M., Samouel, P., \& Hair, N. (2012). Online customer experience in e-retailing: An empirical model of antecedents and outcomes. Journal of Retailing, 88(2), 308-322. https://doi.org/10.1016/j.jretai.2012.03.001

Rubel, M. R. B., \& Kee, D. M. H. (2015). Perceived fairness of performance appraisal, promotion opportunity and nurses turnover intention: The role of organizational commitment. Asian Social Science, 11(9), 183. https://doi.org/10.5539/ass.v11n9p183

Rubel, M. R. B., Kee, D. M. H., \& Rimi, N. N. (2017). The Mediating Role of Work-Family Conflict on Role Stressors and Employee Turnover Intention Relationship in Labour-oriented Organizations. Global Business Review, 18(6), 1384-1399. https://doi.org/10.1177/0972150917713061

Rubel, M. R. B., Rimi, N. N., Yusoff, Y. M., \& Kee, D. M. H. (2018). High Commitment Human Resource Management Practices and Employee Service Behavior: Trust in Management as Mediator. IIMB Management Review. https://doi.org/10.1016/j.iimb.2018.05.006

Rubel, M. R. B., Kee, D. M. H., Rimi, N. N., \& Yusoff, Y. M. (2017). Adapting technology: Effect of high-involvement HRM and organisational trust. Behaviour \& Information Technology, 36(3), 281-293. https://doi.org/10.1080/0144929X.2016.1222552

Ryu, K., Lee, H. R., \& Gon Kim, W. (2012). The influence of the quality of the physical environment, food, and service on restaurant image, customer perceived value, customer satisfaction, and behavioral intentions. International Journal of Contemporary Hospitality Management, 24(2), 200-223. https://doi.org/10.1108/09596111211206141

Saeidi, S. P., Sofian, S., Saeidi, P., Saeidi, S. P., \& Saaeidi, S. A. (2015). How does corporate social responsibility contribute to firm financial performance? The mediating role of competitive advantage, reputation, and

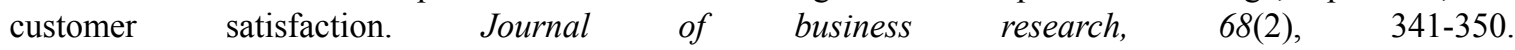
https://doi.org/10.1016/j.jbusres.2014.06.024

Santhanamery, T., \& Ramayah, T. (2015). Understanding the effect of demographic and personality traits on the e-filing continuance usage intention in Malaysia. Global Business Review, 16(1), 1-20. https://doi.org/10.1177/097215091455345

Sekaran, U., \& Bougie, R. (2010). Research Methods for Business: A Skill Building Approach (5th ed.). New Jersey: John Wiley and Sons.

Sekulic, D., \& Mandaric, M. (2014). Models for measuring services quality and customer satisfaction in hotel industry. Актуальні проблеми економіки, (8), 480-487.

Steinhoff, L., \& Palmatier, R. W. (2016). Understanding loyalty program effectiveness: Managing target and bystander effects. Journal of the Academy of Marketing Science, 44(1), 88-107. https://doi.org/10.1007/s11747-014-0405-6

Su, L., Swanson, S. R., \& Chen, X. (2016). The effects of perceived service quality on repurchase intentions and subjective well-being of Chinese tourists: The mediating role of relationship quality. Tourism Management, 52, 82-95. https://doi.org/10.1016/j.tourman.2015.06.012

Subramanian, N., Gunasekaran, A., Yu, J., Cheng, J., \& Ning, K. (2014). Customer satisfaction and competitiveness in the Chinese E-retailing: Structural equation modeling (SEM) approach to identify the role of quality factors. Expert Systems with Applications, 41(1), 69-80. 
Uddin, M. B., \& Akhter, B. (2012). Customer satisfaction in mobile phone services in Bangladesh: A survey research. Management \& Marketing Journal, 10(1).

Wang, C. H., Chen, K. Y., \& Chen, S. C. (2012). Total quality management, market orientation and hotel performance: The moderating effects of external environmental factors. International Journal of Hospitality Management, 31(1), 119-129. https://doi.org/10.1016/j.ijhm.2011.03.013

Wang, Y., \& Feng, H. (2012). Customer relationship management capabilities: Measurement, antecedents and consequences. Management Decision, 50(1), 115-129. https://doi.org/10.1108/00251741211194903

Wu, W. Y., Tsai, C. C., \& Fu, C. S. (2013). The relationships among internal marketing, job satisfaction, relationship marketing, customer orientation, and organizational performance: An empirical study of TFTLCD companies in Taiwan. Human Factors and Ergonomics in Manufacturing \& Service Industries, 23(5), 436-449. https://doi.org/10.1002/hfm.20329

Yee, R. W., Yeung, A. C., \& Cheng, T. C. E. (2011). The service-profit chain: An empirical analysis in high-contact service industries. International Journal of Production Economics, 130(2), 236-245. https://doi.org/10.1016/j.jpe.2011.01.001

Yi, Y. (1990). A critical review of customer satisfaction. American Marketing Association, Chicago.

Yuksel, A., Yuksel, F., \& Bilim, Y. (2010). Destination attachment: Effects on customer satisfaction and cognitive, affective and conative loyalty. Tourism Management, 31(2), 274-284. https://doi.org/10.1016/j.tourman.2009.03.007

Zehir, C., Ertosun, Ö. G., Zehir, S., \& Müceldilli, B. (2012). Total quality management practices' effects on quality performance and innovative performance. Procedia-Social and Behavioral Sciences, 41, 273-280. https://doi.org/10.1016/j.sbspro.2012.04.031

Zeng, J., Phan, C. A., \& Matsui, Y. (2015). The impact of hard and soft quality management on quality and innovation performance: An empirical study. International Journal of Production Economics, 162, 216-226. https://doi.org/10.1016/j.ijpe.2014.07.006

Zhao, L., Lu, Y., Zhang, L., \& Chau, P. Y. (2012). Assessing the effects of service quality and justice on customer satisfaction and the continuance intention of mobile value-added services: An empirical test of a multidimensional model. Decision Support Systems, 52(3), 645-656. https://doi.org/10.1016/j.dss.2011.10.022

\section{Copyrights}

Copyright for this article is retained by the author(s), with first publication rights granted to the journal.

This is an open-access article distributed under the terms and conditions of the Creative Commons Attribution license (http://creativecommons.org/licenses/by/4.0/). 